\title{
Growing, Production and Quality of Thornless Cactus Irrigated With Dairies Effluent
}

\author{
Keivianne da S. L. Reges ${ }^{1}$, Andrezza G. Costa ${ }^{2}$,Vanessa T. da Cunha ${ }^{3}$, Jeane C. Portela ${ }^{4}$, Rafael O. Batista ${ }^{5}$, \\ Vander Mendonça ${ }^{4}$, Joaquim O. Pereira ${ }^{5}$, Gabriela C. de S. Gurgel ${ }^{6}$, Jacineumo F. de Oliveira ${ }^{7}$, \\ Francisco G. C. Freire ${ }^{1}$, Paulo H. M. Gadelha ${ }^{1} \&$ Maria F. S. Diógenes ${ }^{1}$ \\ ${ }^{1}$ Graduate Student of Agronomy, Federal Rural University of Semiarid Region, Mossoró, Brazil \\ ${ }^{2}$ Graduate Student of Agricultural and Environmental Engineering, Federal Rural University of Semiarid Region, \\ Mossoró, Brazil \\ ${ }^{3}$ Graduate Student of Agricultural and Environmental Engineering, Federal University of Recôncavo of Bahia, \\ Cruz das Almas, Brazil \\ ${ }^{4}$ Department of Environmental and Forest Sciences, Federal Rural University of Semiarid Region, Mossoró, \\ Brazil \\ ${ }^{5}$ Department of Engineering and Environmental Sciences, Federal Rural University of Semiarid Region, \\ Mossoró, Brazil \\ ${ }^{6}$ Department of Environmental Management, University of the State of Rio Grande do Norte, Mossoró, Brazil \\ ${ }^{7}$ Graduate Student of Agricultural and Environmental Engineering, Federal University of Lavras, Lavras, Brazil \\ Corresponding Author: Rafael Oliveira Batista, Department of Engineering and Environmental Sciences, Federal \\ Rural University of Semiarid Region, Francisco Mota St, 572-Pres. Costa e Silva, Mossoró, RN, 59625-900, \\ Brazil. Tel: 55-849-8803-8437. E-mail: rafaelbatista@ufersa.edu.br
}

Received: January 27, $2019 \quad$ Accepted: June 25, $2019 \quad$ Online Published: August 31, 2019

doi:10.5539/jas.v11n14p175 URL: https://doi.org/10.5539/jas.v11n14p175

\begin{abstract}
The environmental pollution coming from dairies industries are the most hazardous of the economy sector due to the great amount of garbage produced. This work aimed it evaluating the dairies effluent on the morphometric, productive, bromatological, and nutritional effects of the thornless cactus. One trial was carried out it the Water Reuse Experimental Station during the period from April to December 2015. The experiment was carried out in randomized blocks design, with five treatments and five replications, totaling 25 experimental units. The treatments were irrigation with water of well (T1), irrigation with $10 \%$ of annual dose plus water of well (T2), irrigation with $20 \%$ of annual dose plus water of well (T3), irrigation with $30 \%$ of annual dose plus water of well (T4), and irrigation with $40 \%$ of annual dose plus water of well (T5). The growth parameteres determinations parameteres (production and quality) of thornless cactus were achieved at 240 days after planting. The highest productivity $\left(28.2 \mathrm{Mg} \mathrm{ha}^{-1}\right)$ was achieved with the treatment $\mathrm{T} 4$. The nitrogen concentrations were significative to thornless cactus, whereas the treatment T4 increased mostly the Nitrogen content in the plants. Then, the T4 treatment predominated, since it enhanced the crop productivity about crude protein and Nitrogen contents.
\end{abstract}

Keywords: agroindustry wastewater, cacti, forage crop, water reuse

\section{Introduction}

The thornless cactus (Cereus hildmannianus K. Schum), among forage crops, belongs to cacti botanical family, foun frequently in arid and semiarid environments, requiring a low water supply, and has great potential to produce forage and to supply protein (Dubeux Júnior et al., 2015; Souza et al., 2017). Thornless cactus is important for native forests preservation and to produce low-cost forages. Thus, the reuse of dairies wastewater (DWW) in semiarid regions is an important water supply alternative and needs to be better studied.

The agriculture increasing water necessity and the high amount of agroindustry wastewater have been intensifying the water reuse on agricultural and county environments, increasing the need for environmental quality and its preservation (Oliveira, Rodrigues, Fia, Vilela, \& Mafra, 2017; Oliveira et al., 2017a). The DWW 
has high nutritional content, salts and organic matter, also has great contaminant potential if by misuse (Formentini-Schmitt et al., 2018).

In this sense, laying the DWW on the soil is a very promoting alternative to the destination, reducing the total expenses of the agricultural proceedings, provided that the treatment and management of this liquid residue minimizes negative impacts on the soil (Libutti et al., 2018). Rodríguez-Liébana, Elgouzia, Mingorancea, Castilloa, and Peña (2014), and Kihila, Mtei, and Njau (2014) stated the fertigation with agroindustry wastewater doses is highly beneficial to the socio-economy and to the environment mainly; reducing the dropping of the effluents on the rivers and lakes, the chemical fertilizers necessity; and to the recovering of the soil nutrients.

Many risks of contaminating the of soils and crops by pathogens, of poisoning by heavy metals associated to the origin, quantity and quality of the effluent there exist (Becerra-Castro et al., 2015; Kunhikrishnan et al., 2017), besides the salts accumulation, $\mathrm{pH}$ disbalance and reduction of the soil infiltration rate due to inadequate management (Bedbabis, Rouina, Boukhris, \& Ferrara, 2014). Although, the irrigation with wastewater increases biomass production and forage productivity (Fia, Boas, Campos, Fia, \& Souza, 2014; Saraiva, A. T. Matos, M. P. Matos, \& Miranda, 2018). Gheri, Ferreira, and Cruz (2003), and Morrill et al. (2012) studying the reuse of agroindustry residues to the soil, aiming at producing forage, analysed the acid whey nutritional contents and obtained the following results (N: 700; Ca: 900; Mg: 100; K: 1,520; P: $500 \mathrm{mg} \mathrm{L}^{-1}$ ) and (N: 860; Ca: 220; Mg: 180; K: 1,500; P: $300 \mathrm{mg} \mathrm{L}^{-1}$ ), respectively. These indicate relevant results about the forage productivity.

In this context, this work aimed it evaluating the effects of the dairy effluent application on the morphometric, productive, bromatological, and nutritional attributes upon the thornless cactus.

\section{Method}

\subsection{Description of the Experimental Field and Climate Conditions}

The trial was carried out at the Water Reuse Experimental Station (WRES), during the period from April to December 2015, in a field of $770 \mathrm{~m}^{2}(20 \mathrm{~m}$ width $\times 38.5 \mathrm{~m}$ long $)$, at Federal Rural University of Semiarid (UFERSA), campus Leste, BR 110-Km 47, Presidente Costa and Silva, Mossoro/RN, geographic coordinates: $5^{\circ} 12^{\prime 2} 29.32^{\prime \prime} \mathrm{S} ; 37^{\circ} 19^{\prime} 06.12^{\prime \prime} \mathrm{W} ; 18 \mathrm{~m}$ of altitude.

According to the Köppen-Geiger classification, the climate of that region is classified as BSh', warm and dry, with rainy season from May to July, and very dry season from September to December, with annual precipitation less than $650 \mathrm{~mm}$ and annual average temperature slightly greater than $26.5^{\circ} \mathrm{C}$ (Alvares, Stape, Sentelhas, Gonçalves, \& Sparovek, 2014). The climate data was used to estimate the reference evapotranspiration (ETo) by the Penman-Monteith equation (Allen, Pereira, Raes, \& Smith, 2006). The Doorenbos and Pruitt's (1977 equation modified by Mantovani and Costa (1998) was used to estimate the ETc applying the crop coefficient (kc) 1.0. The data of the rainfall and the reference evapotranspiration (ETo), and of the average air temperature and the solar radiation occurred during the experiment are presented in Figures 1 and 2, respectively.

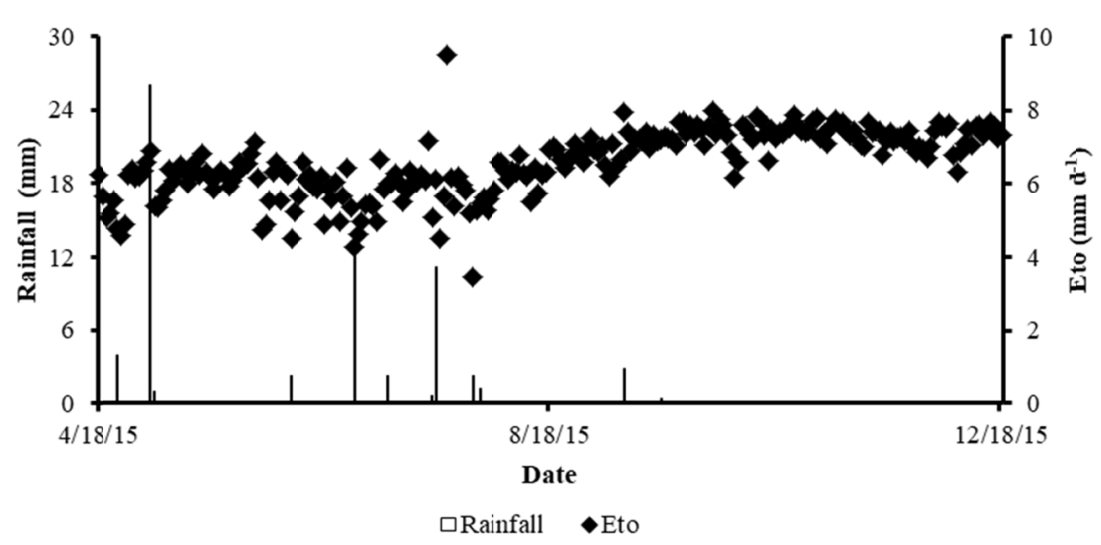

Figure 1. Rainfall and ETo during the experiment period 


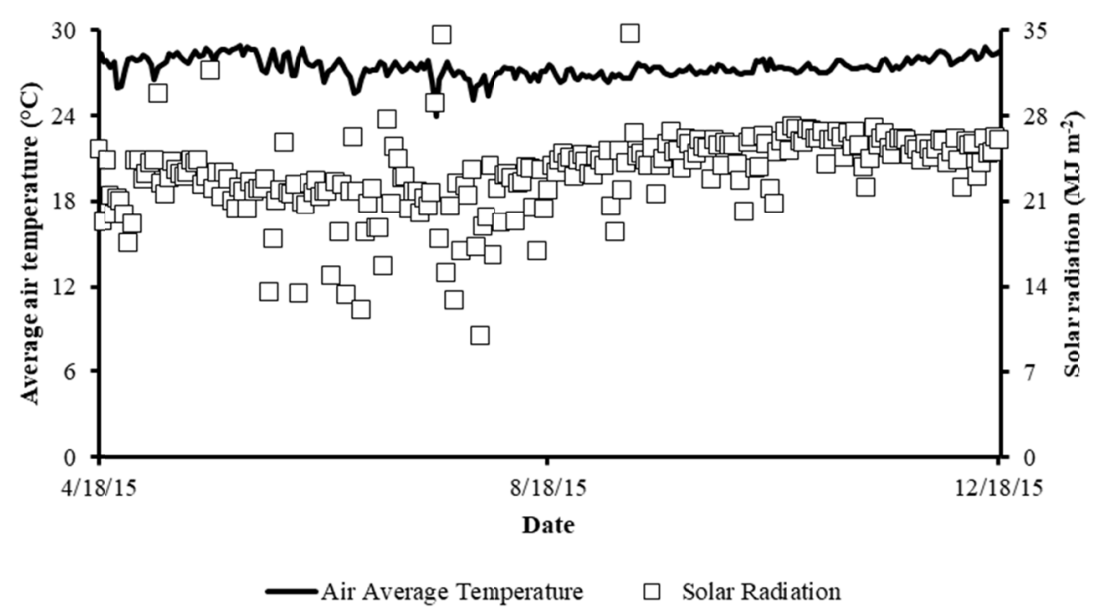

Figure 2. Average air temperature and solar radiation during the experiment

The soil of the experimental area is classified as eutrophic Red Yellow Argisol according to the Brazilian Soil Classification System (Embrapa, 2013).

\subsection{Experimental Procedures}

The trial was carried out with the partnership of the Company in Mossoró-RN, Brazil. The main products of that company are pasteurized milk, dairy beverage, milk candy, creamy cheese, curd cheese, Minas frescal cheese, and backcountry butter.

The experimental area was installed at WRES, and fertigated with dairy effluent coming from the facultative aerated lagoon. The company drops $35 \mathrm{~m}^{3}$ a day of effluent coming from the processing of products and of the sanitization proceedings (Marques et al., 2016).

The dairy effluent from the company was transported to the experimental area at WRES/UFERSA in five $20 \mathrm{~L}$ impermeable reservoirs. The transportation was done every day of the irrigation of the thornless cactus to avoid missing the effluent nutritional properties.

Table 1. Physical-chemical characteristics of the dairy effluent treated (DE) with respective average values

\begin{tabular}{ll}
\hline Variables & Average values \\
\hline Biochemical oxygen demand $\left(\mathrm{mg} \mathrm{L}^{-1}\right)$ & 1504.00 \\
Chemical Oxygen Demand $\left(\mathrm{mg} \mathrm{L}^{-1}\right)$ & 2637.33 \\
Nitrogen $\left(\mathrm{mg} \mathrm{L}^{-1}\right)$ & 49.33 \\
Phosphorus $\left(\mathrm{mg} \mathrm{L}^{-1}\right)$ & 39.00 \\
Potassium $\left(\mathrm{mg} \mathrm{L}^{-1}\right)$ & 20.97 \\
Sodium $\left(\mathrm{mg} \mathrm{L}^{-1}\right)$ & 32.19 \\
Calcium $\left(\mathrm{mg} \mathrm{L}^{-1}\right)$ & 15.43 \\
Magnesium $\left(\mathrm{mg} \mathrm{L}^{-1}\right)$ & 21.87 \\
Electric conductivity $(\mathrm{dS} \mathrm{m}$ & \\
$\mathrm{pH}$ & 4.60 \\
$\mathrm{SAR}\left(\mathrm{mmol}_{\mathrm{c}} \mathrm{L}^{-1}\right)^{0,5}$ & 7.88 \\
\hline
\end{tabular}

\subsubsection{Experimental Design}

The water from public supply came from the Rio Grande do Norte, of Water and Sewer Company (CAERN), stored in $16 \mathrm{~m}^{3}$ impermeabilized reservoirs shaded by cashew trees to avoid the water heating.

The experimental area was delimited with $49 \mathrm{~m}^{2}$ and divided into 25 parcels $1.0 \mathrm{~m}$ length $\times 1.0 \mathrm{~m}$ wide $\left(1.0 \mathrm{~m}^{2}\right)$, spaced $0.50 \mathrm{~m}$ apart between blocks and parcels. The trial was carried out in randomized block design, in which the effect of the application of different proportions of a dairy effluent upon the thornless cactus was evaluated. 
The treatments were based on the criteria of EPA (1981), and on the water necessity of the crop: treatment T1-water from public supply (WPS); treatment T2-0.1 $\times$ annual water volume (LW) of EPA plus WPS; treatment T3-0.2 $\times$ LW of EPA plus WPS; treatment T4-0.3 $\times$ LW of EPA plus WPS; and treatment T5-0.4 $\times$ LW of EPA plus WPS. Thus, the doses 0, 230.8, 461.6, 692.4 and $923.2 \mathrm{~m}^{3} \mathrm{ha}^{-1}$ year $^{-1}$ of DWW corresponded to the treatments $\mathrm{T} 1, \mathrm{~T} 2, \mathrm{~T} 3, \mathrm{~T} 4$, and $\mathrm{T} 5$, respectively.

The application of the water coming from the public supply was carried out through the following components:

a) one $16 \mathrm{~m}^{3}$ reservoir of concrete; b) one $0.5 \mathrm{cv}$ pump with a $130-\mu \mathrm{m}$ mesh filter; c) one main $32 \mathrm{~mm}$ of diameter PVC tube, and d) twenty $2.0 \mathrm{~L} \mathrm{~h}^{-1}$ branch tubes with droplets non-self-compensating and emitters spaced $0.30 \mathrm{~m}$ apart.

The application of dairy effluent was carried out as the following: a) Mixing and homogenization of the effluent to avoid sedimentation; b) Measurement of the specified quantity of the effluent with an $1 \mathrm{~L}$ scaled beaker; c) Dropping the amount to a watering can; and d) Laying the effluent with the watering can on the soil in every experimental parcel, avoiding the direct touch of the effluent on the body of the thornless cactus.

The planting of the thornless cactus was carried out at Abril 18, 2015. Four $0.25 \mathrm{~m}$ height seedlings were planted in each parcel $0.15 \mathrm{~m}$ deep in the soil and spaced $0.50 \mathrm{~m}$ apart. At all crop cycle long neither was done amendments or top-dressing fertilization, as suggested by Mesquita (2016).

In the treatments T1 to T5, the irrigation with water coming from the public supply (WPS) occurred fortnightly, since the planting of thornless cactus at Abril 15, 2015 until finishing the experiment at December 18, 2015. The application of the dairy effluent begun on June 1, 2015 aiming at avoiding harming the seedlings during the adaptation pace (Oliveira et al., 2017).

From the beginning of the thornless cactus cropping cycle until the harvest at 240 days after planting, a crude irrigation blade of $227.14 \mathrm{~mm}$ was applied, which was distributed in five proportions of the DWW and water coming from public supply (WPS).

The harvest of the thornless cactus was carried out manually after 240 days of the planting. The analysis of the plant development was carried out considering the variables productivity (PROD), fresh mass (FM), dry mass (DM), plant height (PH), cladode length (CL) and cladode number (NC).

In quality's evaluation of the cactus produced, bromatological and chemical analyses were carried out to assess the variables: acid detergent fiber (ADF), neutral detergent fiber (NDF), crude protein (CP), nitrogen (N), phosphorus $(\mathrm{P})$, sodium $(\mathrm{Na})$, potassium $(\mathrm{K})$, calcium $(\mathrm{Ca})$ and magnesium $(\mathrm{Mg})$ according to EMBRAPA's methodology (Silva, 2009; Detmann et al., 2012).

The crude protein (CP) was calculated through the equation Equation 1, following Detmann et al. (2012).

$$
\mathrm{CP}=\frac{[\mathrm{N}]}{10} \times 6.25
$$

Where, CP: crude protein, \%; $\mathrm{N}$ : total nitrogen by Kjeldahl method, $\mathrm{g} \mathrm{kg}^{-1}$.

\subsection{Statistical Analyzes}

The morphometric, bromatological and chemical data of the thornless cactus were submitted to analysis of variance through the software SISVAR (Ferreira, 2014), performing Tukey's test and orthogonal contrasts for multiple comparisons of means (Mesquita, 2016).

The contrasts were: 1) treatment $\mathrm{T} 5$ versus other treatments (T1, T2, T3 and T4); 2) treatment $\mathrm{T} 4$ versus treatments $\mathrm{T} 1, \mathrm{~T} 2$ and $\mathrm{T} 3 ; 3$ ) treatment $\mathrm{T} 3$ versus treatments $\mathrm{T} 1$ and $\mathrm{T} 2$; and 4) treatment $\mathrm{T} 2$ versus treatment $\mathrm{T} 1$. The combination of the contrasts with the averages of the treatments was expressed as follows, as proposed by Mesquita (2016):

$$
\begin{gathered}
\mathrm{C} 1=12 \mathrm{~m}_{1}+12 \mathrm{~m}_{2}+8 \mathrm{~m}_{3}+10 \mathrm{~m}_{4}-42 \mathrm{~m}_{5} \\
\mathrm{C} 2=30 \mathrm{~m}_{1}+30 \mathrm{~m}_{2}+20 \mathrm{~m}_{3}-80 \mathrm{~m}_{4} \\
\mathrm{C} 3=6 \mathrm{~m}_{1}+6 \mathrm{~m}_{2}-12 \mathrm{~m}_{3} \\
\mathrm{C} 4=6 \mathrm{~m}_{1}-6 \mathrm{~m}_{2}
\end{gathered}
$$

\section{Results and Discussion}

The morphometric variables were significant for productivity (PROD), fresh mass (FM), dry mass (DM), plant height $(\mathrm{PH})$, cladode length $(\mathrm{CL})$ and cladode number per plant $(\mathrm{CN})$ as shown in Table 2. 
Table 2. Productive and morphometric variables of thornless cactus irrigated with proportions of dairy effluent and water from the public supply

\begin{tabular}{|c|c|c|c|c|c|c|}
\hline \multirow{2}{*}{ Treatments } & \multicolumn{6}{|c|}{ Productive and morphogenic characteristics } \\
\hline & $\begin{array}{l}\text { PROD } \\
\end{array}$ & FM & $\mathrm{DM}$ & $\mathrm{PH}$ & $\mathrm{CL}$ & $\mathrm{CN}$ \\
\hline & $\mathrm{Mg} \mathrm{ha}^{-1}$ & \multicolumn{2}{|c|}{----------- $\mathrm{kg} \mathrm{m}^{-2}$---------- } & \multicolumn{3}{|c|}{ |---------------- m ---------------- } \\
\hline $\mathrm{T} 1$ & $6.14 \mathrm{a}$ & $0.61 \mathrm{a}$ & $0.05 \mathrm{a}$ & $0.30 \mathrm{a}$ & $0.22 \mathrm{ab}$ & $1.10 \mathrm{a}$ \\
\hline $\mathrm{T} 2$ & $11.66 \mathrm{~b}$ & $1.17 \mathrm{~b}$ & $0.08 \mathrm{~b}$ & $0.29 \mathrm{a}$ & $0.21 \mathrm{a}$ & $1.50 \mathrm{a}$ \\
\hline $\mathrm{T} 3$ & $18.73 \mathrm{c}$ & $1.87 \mathrm{c}$ & $0.13 \mathrm{c}$ & $0.36 \mathrm{ab}$ & $0.25 \mathrm{ab}$ & $1.36 \mathrm{a}$ \\
\hline $\mathrm{T} 4$ & $28.17 \mathrm{~d}$ & $2.82 \mathrm{~d}$ & $0.21 \mathrm{~d}$ & $0.45 b$ & $0.31 \mathrm{~b}$ & $1.64 \mathrm{a}$ \\
\hline T5 & $10.38^{\mathrm{a}}$ & $1.04 \mathrm{~b}$ & $0.07 \mathrm{ab}$ & $0.36 \mathrm{ab}$ & $0.24 \mathrm{ab}$ & $1.38 \mathrm{a}$ \\
\hline Average & 15.02 & 1.50 & 0.11 & 0.35 & 0.24 & 1.40 \\
\hline $\mathrm{CV}(\%)$ & 6.85 & 6.85 & 8.89 & 18.27 & 20.43 & 20.93 \\
\hline Standard-error & 0.46 & 0.05 & 0.01 & 0.03 & 0.02 & 0.13 \\
\hline Probability & $0.00^{* *}$ & $0.00^{* *}$ & $0.00^{* *}$ & $0.01^{*}$ & $0.04^{*}$ & $0.09^{\mathrm{NS}}$ \\
\hline Contrastes & \multicolumn{6}{|c|}{ Probability of contrasts (decimal) } \\
\hline $\mathrm{C}_{1}: \mathrm{T} 5 \mathrm{Vs}(\mathrm{T} 1+\mathrm{T} 2+\mathrm{T} 3+\mathrm{T} 4)$ & $0.0000^{* *}$ & $0.0000^{* *}$ & $0.0000^{* *}$ & $0.7395^{\mathrm{NS}}$ & $0.9414^{\mathrm{NS}}$ & $0.9337^{\mathrm{NS}}$ \\
\hline $\mathrm{C}_{2}: \mathrm{T} 4 \mathrm{Vs}(\mathrm{T} 1+\mathrm{T} 2+\mathrm{T} 3)$ & $0.0000^{* *}$ & $0.0000^{* *}$ & $0.0000^{* *}$ & $0.0009^{* *}$ & $0.0034^{*}$ & $0.0476^{*}$ \\
\hline $\mathrm{C}_{3}: \mathrm{T} 3 \mathrm{Vs}(\mathrm{T} 1+\mathrm{T} 2)$ & $0.0000^{* *}$ & $0.0000^{* *}$ & $0.0000^{* *}$ & $0.0693^{\mathrm{NS}}$ & $0.2314^{\mathrm{NS}}$ & $0.7127^{\mathrm{NS}}$ \\
\hline $\mathrm{C}_{4}: \mathrm{T} 2 \mathrm{Vs} \mathrm{T} 1$ & $0.0000^{* *}$ & $0.0000^{* *}$ & $0.0001^{* *}$ & $0.7860^{\mathrm{NS}}$ & $0.6904^{\mathrm{NS}}$ & $0.0459^{*}$ \\
\hline
\end{tabular}

Note. T1-water from public supply only (WPS), T2-0.1 $\times$ LW of EPA plus WPS, T3-0.2 $\times$ LW of EPA plus WPS, T4-0.3 $\times$ LW of EPA plus WPS, and T5-0.4 $\times$ LW of EPA plus WPS; PROD-Produtivity; FM-Fresh mass; DM-Dry mass; PH-Plant height; CL-Cladode lenght; CN-Cladode number per plant; $\mathrm{C}_{1}=12 \mathrm{~m}_{1}+12 \mathrm{~m}_{2}+8 \mathrm{~m}_{3}$ $+10 \mathrm{~m}_{4}-42 \mathrm{~m}_{5} ; \mathrm{C}_{2}=30 \mathrm{~m}_{1}+30 \mathrm{~m}_{2}+20 \mathrm{~m}_{3}-80 \mathrm{~m}_{4} ; \mathrm{C}_{3}=6 \mathrm{~m}_{1}+6 \mathrm{~m}_{2}-12 \mathrm{~m}_{3} ; \mathrm{C}_{4}=6 \mathrm{~m}_{1}-6 \mathrm{~m}_{2}$. Averages followed by same latters in the column did not differ statisticly by Tukey's test at $5 \%$ of probability. ${ }^{* *}$ and ${ }^{*}$ significative at 1 and $5 \%$ of probality by $\mathrm{F}$ test, respectively. ${ }^{\mathrm{NS}}$-non-significative.

The dose of $692.4 \mathrm{~m}^{3} \mathrm{ha}^{-1}$ of DWW (T4) significantly increased the PROD, FM, DM and PH variables, resulting in a major of $28.17 \mathrm{Mg} \mathrm{ha}^{-1}, 2.82 \mathrm{~kg} \mathrm{~m}^{-2}, 0.21 \mathrm{~kg} \mathrm{~m}^{-2}$ and $0.45 \mathrm{~m}$, and an increasing of 459, 460, 429 and $149 \%$, respectively, about the thornless cactus responses under control treatment (T1). Mathiyarasu et al. (2017) used an $800 \mathrm{~mm}^{-1}$ blade water of slaughterhouse and domestic sewage wastewater, and obtained the productivity of 8.4 and 4.4 $\mathrm{Mg} \mathrm{ha}^{-1} \mathrm{DM}$ of sunflower and alfalfa, respectively. While Bezerra et al. (2017) obtained a productivity of $2.28 \mathrm{Mg} \mathrm{ha}^{-1} \mathrm{DM}$ of Marandu grass (Brachiaria brizantha cv. Marandu) with dosages of $120 \mathrm{~m}^{3} \mathrm{ha}^{-1} \mathrm{of}$ cassava processing residual water.

There was no significance for length and number of cladodes, in relation to control treatment, this fact is attributed to the short cultivation period of the cacti of only 240 days. If they were cultivated for 720 days, probably these characteristics would have presented statistical difference. Such a similar result to those observed by Queiroz et al. (2015) and Cunha et al. (2012) in studies with forage palm and irrigation blades in semiarid region conditions. However, Barbosa et al. (2017) observed an increase in the number of cladodes of $3^{\text {rd }}$ generation, resulting in greater $\mathrm{CO}_{2}$ assimilative ability and photosynthetic activity, enhancing the cell division and the increase of fresh mass, dry mass, length and number of cladodes of the Mexican erect prickly pear (Opuntia stricta (Haw.) Haw. Silva et al. (2016) obtained 15,5 cladodes per plant, applying $200 \mathrm{~kg} \mathrm{ha}^{-1}$ of N, 150 $\mathrm{kg} \mathrm{ha}^{-1}$ of $\mathrm{P}_{2} \mathrm{O}_{5}$ and $100 \mathrm{~kg} \mathrm{ha}^{-1}$ of $\mathrm{K}_{2} \mathrm{O}$. The authors also emphasized that an increase of the rainfall at the end of the trial enhanced the vegetative performance of the forage, resulting also in significative effects upon the cladode area and the plant height.

In the $\mathrm{T} 4$ treatment provided a $\mathrm{PH}$ maximum of $0.45 \mathrm{~m}$, a significative result and $50 \%$ superior to $0.30 \mathrm{~m}$ obtained from the treatment T1 (control). Pereira, Silva, Zolnier, Morais, and Santos (2015), and Lima et al. (2016) obtained a PH of $0.49 \mathrm{~m}$ and $1.15 \mathrm{~m}$, respectively, evaluating the forage palm irrigated in semiarid conditions.

In this work, only positive and significant (5\%) effects of the orthogonal contrasts were observed for $\mathrm{pH}$, and for $\mathrm{C}$ and $\mathrm{CN}$ at $1 \%$ probability, thus demonstrating the nutritional and water supply effects for the thornless cactus in a semiarid environment.

Queiroz et al. (2015), and Barbosa et al. (2017) confirm that the macro and micronutrients coming from wastewater can enhance the cacti productivity in semiarid regions, even being the water supply fundamental to the plant performance in these climate condition (Oliveira et al., 2017; Klomjek., 2016). However, dairy 
effluents have high terores salts, including sodium, which can cause salinization and in agricultural areas sodification handled improperly reused. For this reason, it is essential to employ technical criteria that allow agricultural reuse with its mitigated environmental impacts.

In Table 3 shows the bromatological variables and nutritional status of thornless cactus at 240 days after planting. There was no significance for the application of the treatments for acid detergent fiber (ADF), neutral detergent fiber $(\mathrm{NDF})$, potassium $(\mathrm{K})$ and magnesium $(\mathrm{Mg})$ at $5 \%$ of probability for Tukey's test when compared to treatment control. The variables $\mathrm{CP}, \mathrm{N}, \mathrm{Ca}$ and $\mathrm{Na}$ present significant differences at $1 \%$ of probability by the $\mathrm{F}$ test, while the variable $\mathrm{P}$ was also significant at $5 \%$ probability by the test $\mathrm{F}$. Analyzing the variables $\mathrm{CP}, \mathrm{N}, \mathrm{Ca}$, $\mathrm{Na}$ and $\mathrm{P},(\mathrm{T} 1)$ does not differ statistically from the others, by the Tukey test at $5 \%$ probability, indicating that the nutrients present in the dairy waste water are in concentrations that do not affect the bromatological characteristics nor the accumulation of nutrients in the vegetable tissue.

Table 3. Bromatological characteristics and nutritional composition of thornless cactus irrigated with proportions of dairy effluent and public water supply

\begin{tabular}{|c|c|c|c|c|c|c|c|c|c|}
\hline Treatments & $\mathrm{ADF}$ & NDF & $\mathrm{CP}$ & $\mathrm{N}$ & $\mathrm{P}$ & $\mathrm{K}$ & $\mathrm{Ca}$ & $\mathrm{Mg}$ & $\mathrm{Na}$ \\
\hline & \multicolumn{3}{|c|}{ 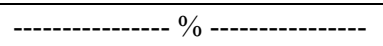 } & \multicolumn{5}{|c|}{ 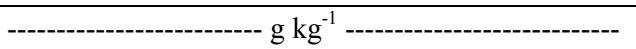 } & $\mathrm{mg} \mathrm{kg}^{-1}$ \\
\hline $\mathrm{T} 1$ & $21.58 \mathrm{a}$ & $25.91 \mathrm{a}$ & $15.37 \mathrm{ab}$ & $24.29 \mathrm{ab}$ & $0.03 \mathrm{ab}$ & $3.21 \mathrm{a}$ & $107.98 \mathrm{ab}$ & $37.44 \mathrm{a}$ & $247.20 \mathrm{ab}$ \\
\hline $\mathrm{T} 2$ & $20.71 \mathrm{a}$ & $28.75 \mathrm{a}$ & $15.09 \mathrm{ab}$ & $24.19 \mathrm{ab}$ & $0.05 \mathrm{~b}$ & $5.28 \mathrm{a}$ & $139.93 b$ & $44.38 \mathrm{a}$ & $164.50 \mathrm{a}$ \\
\hline $\mathrm{T} 3$ & $21.47 \mathrm{a}$ & $27.86 \mathrm{a}$ & $12.72 \mathrm{a}$ & $20.34 \mathrm{a}$ & $0.04 \mathrm{ab}$ & $7.98 \mathrm{a}$ & $123.63 b$ & $41.82 \mathrm{a}$ & $179.37 \mathrm{a}$ \\
\hline $\mathrm{T} 4$ & $18.93 \mathrm{a}$ & $27.03 \mathrm{a}$ & $17.57 \mathrm{~b}$ & $28.11 b$ & $0.03 \mathrm{ab}$ & $3.77 \mathrm{a}$ & $82.33 \mathrm{a}$ & $29.77 \mathrm{a}$ & $211.59 \mathrm{ab}$ \\
\hline T5 & $19.10 \mathrm{a}$ & $25.62 \mathrm{a}$ & $16.13 b$ & $25.81 \mathrm{~b}$ & $0.03 \mathrm{a}$ & $2.36 \mathrm{a}$ & $121.00 \mathrm{~b}$ & $38.56 a$ & $311.65 b$ \\
\hline Average & 20.36 & 27.03 & 15.37 & 24.61 & 0.04 & 4.52 & 114.97 & 38.59 & 222.86 \\
\hline CV $(\%)$ & 9.62 & 7.04 & 10.04 & 10.04 & 29.82 & 80.51 & 16.70 & 19.56 & 25.59 \\
\hline Standad-error & 0.876 & 0.851 & 0.690 & 1.104 & 0.005 & 1.628 & 8.589 & 3.375 & 25.509 \\
\hline Probability & $0.1272^{\mathrm{NS}}$ & $0.0955^{\mathrm{NS}}$ & $0.0025^{* *}$ & $0.0025^{* *}$ & $0.0162^{*}$ & $0.1701^{\mathrm{NS}}$ & $0.0031^{* *}$ & $0.0667^{\mathrm{NS}}$ & $0.0063^{* *}$ \\
\hline Contrast $\mathrm{C}_{1}: \mathrm{T} 5 \mathrm{Vs}(\mathrm{T} 1+\mathrm{T} 2+\mathrm{T} 3+\mathrm{T} 4)$ & $0.1279^{\mathrm{N}} \overline{\mathrm{S}}$ & $0.0872^{\mathrm{NS}}$ & $0.3010^{\mathrm{NS}}$ & $0.3059^{\mathrm{NS}}$ & $0.0493^{*}$ & $0.1931^{\mathrm{NS}}$ & $0.4764^{\mathrm{NS}}$ & $0.7990^{\mathrm{NS}}$ & $0.0015^{* *}$ \\
\hline Contrast $\mathrm{C}_{2}: \mathrm{T} 4 \mathrm{Vs}(\mathrm{T} 1+\mathrm{T} 2+\mathrm{T} 3)$ & $0.0382^{*}$ & & $0.0019^{* *}$ & $0.0020^{* *}$ & $0.0955^{\mathrm{NS}}$ & $0.4665^{\mathrm{NS}}$ & $0.0007^{* *}$ & $0.0103^{*}$ & $0.6816^{\mathrm{NS}}$ \\
\hline Contrast $\mathrm{C}_{3}: \mathrm{T} 3 \mathrm{Vs}(\mathrm{T} 1+\mathrm{T} 2)$ & $0.7615^{\mathrm{NS}}$ & $0.6185^{\mathrm{NS}}$ & $0.0090^{* *}$ & $0.0087^{* *}$ & $0.9606^{\mathrm{NS}}$ & $0.0787^{\mathrm{NS}}$ & $0.9755^{\mathrm{NS}}$ & $0.8284^{\mathrm{NS}}$ & $0.4092^{\mathrm{NS}}$ \\
\hline Contrast $\mathrm{C}_{4}: \mathrm{T} 2 \mathrm{Vs} \mathrm{T} 1$ & $0.4910^{\mathrm{NS}}$ & $0.0314^{*}$ & $0.7774^{\mathrm{NS}}$ & $0.8006^{\mathrm{NS}}$ & $0.0078^{* *}$ & $0.3813^{\mathrm{NS}}$ & $0.0182^{*}$ & $0.1650^{\mathrm{NS}}$ & $0.0358 *$ \\
\hline
\end{tabular}

Note. T1-water from puclis supply only (WPS), T2-0.1 $\times$ LW of EPA plus WPS, T3-0.2 $\times$ LW of EPA plus WPS, T4-0.3 $\times$ LW of EPA plus WPS, and T5-0.4 $\times$ LW of EPA plus WPS; ADF-Acid Detergente Fiber; NDF-Neutral Detergent Fiber; CP-Crude Protein; N-Nitrogen; P-Phosphorus; Na-Sodium; K-Potassium; Ca-Calcium; Mg-Magnesium; Fe-Iron; Mn-Manganese; Zn -Zinc; Cu-Copper. $\mathrm{C}_{1}=12 \mathrm{~m}_{1}+12 \mathrm{~m}_{2}+8 \mathrm{~m}_{3}+10$ $\mathrm{m}_{4}-42 \mathrm{~m}_{5} ; \mathrm{C}_{2}=30 \mathrm{~m}_{1}+30 \mathrm{~m}_{2}+20 \mathrm{~m}_{3}-80 \mathrm{~m}_{4} ; \mathrm{C}_{3}=6 \mathrm{~m}_{1}+6 \mathrm{~m}_{2}-12 \mathrm{~m}_{3} ; \mathrm{C}_{4}=6 \mathrm{~m}_{1}-6 \mathrm{~m}_{2} ;{ }^{1}$ Averages followed same latters in the column do not differ statisticly by Tukey's test at $5 \%$ of probability. ${ }^{* *}$ and ${ }^{*}$ Significative at 1 and $5 \%$ of probality $\mathrm{F}$ test, respectively. ${ }^{\mathrm{NS}}$-non-significative at $5 \%$ of probability by $\mathrm{F}$ test.

For Santos et al. (2017) the forage of best quality is obtained when CP is higher than 12\% and NDF less than $60 \%$, such a conditions in which the results of the present study fit, unlike the $53.02 \%$ NDF obtained by Emparn (2013) in studies with thornless cactus.

It is also worth noting that the average results of CP and NDF obtained among all treatments were superior to $8.17 \%$ and inferior to $65 \%$, respectively, is considered as a minimum requirement for protein availability and non-limiting effects in the digestive capacity of the animals (Emparn, 2013; Van Soest, 1965). When analyzing the orthogonal contrasts, it was observed that the variables ADF and CP presented significant contrasts $\mathrm{C} 2$ and C3 at 1\% probability, therefore, it was emphasized that the treatments T4 and T3 provided better thornless cactus fiber and protein responses with regards of the other treatments.

According to Solati, Jørgensen, Eriksen, and Søegaard (2017), although the nutritional composition of wastewater is the main responsible for the changes and the dynamics in the development of forage cultivars. The sodium concentration of the dairy wastewater (Donatti, Gomes, Menegassi, Tommaso, \& Rossi, 2017) can provide osmotic disbalances of the root cells and, consequently, affecting the uptake of macronutrients, such as nitrogen, the main responsible for the lignification processes and fot the growth of the cell wall, resulting direct effects on NDF, ADF and CP. 
In studies with bovine biofertilizer, Alonso and Costa (2017) verified linear growth up to the third harvest for the NDF and CP variables, applying $20 \mathrm{~m}^{3} \mathrm{ha}^{-1}$ in the forage crop B. brizantha cv. Xaraés. While Moreira et al. (2017) observed a reduction of $24.5 \%$ to $17.5 \%$ of $\mathrm{CP}$ with the increase of the harvest interval in the cassava crop. The same authors also reported that there is a tendency of increasing the fiber and protein contents in the first harvest, but a reduction with the crop aging as a function of the increase of dry matter, and an increase in the $\mathrm{C} / \mathrm{N}$ ratio. In this sense, Bjarnadóttir, Aðalbjörnsson, Nilsson, Slizyte, and Roleda, (2018) pointed out that the increasing of nitrogen enhances the production of glutamic acid, one of the main compounds responsible for the formation of proteins in vegetables.

Values compiled by Moraes, Costa, and Araújo (2011) presented contents of the bromatological variables unlikely for the regular cactus and for thornless cactus. The percentages of DM, ANF, and ADF were higher for thornless cactus, with values equivalent to $14.43 \%, 56.62 \%$, and $29.90 \%$, respectively. In contrast with $8.56 \%$ of $\mathrm{DM}, 37.56 \%$ of NDF and $19.72 \%$ of ADF composed the regular cactus.

The highest concentration of $\mathrm{N}$ in cladodes was $28.11 \mathrm{~kg} \mathrm{~kg}^{-1}$ after application of $692.4 \mathrm{~m}^{3} \mathrm{ha}^{-1} \mathrm{DWW}$ (T4). Although, this result was significant with respect of the treatment $\mathrm{T} 3\left(20.34 \mathrm{~g} \mathrm{~kg}^{-1}\right.$ of N) when compared to control (24.29 $\mathrm{g} \mathrm{kg}^{-1}$ of $\mathrm{N}$ in cladodes), was not significant, even representing an increase of $18.78 \%$. Similar results were obtained by Caruso, Mauceri, Cavallaro, Borin, and Barbera (2018) after application of wastewater from the processing of olive oil in durum wheat (Triticum durum desf.) in semiarid Mediterranean conditions. Kessler, Sampaio, Sorace, Lucs, and Palma (2014) observed concentrations of $30.33 \mathrm{~g} \mathrm{~kg}^{-1}$ of N with applications of $300 \mathrm{~m}^{3} \mathrm{ha}^{-1}$ of swine wastewater, $67.50 \%$ higher than the $18.11 \mathrm{~g} \mathrm{~kg}^{-1}$ obtained in the treatment control.

Nitrogen is the nutrient that plants require in larger amounts. It is a constituent of many plant cell components, including chlorophyll, amino acids and nucleic acids (Taiz \& Zeiger, 2013). Fertigation with treated dairy effluent was sufficient to meet the crop demand, regardless of the applied dose.

For phosphorus, the highest concentrations in cladodes were $0.05 \mathrm{~g} \mathrm{~kg}^{-1}$ of $\mathrm{P}$ after doses of $230.87 \mathrm{~m}^{3} \mathrm{ha}^{-1}$ of dairy wastewater, a result not significant in relation to the control. These results were lower than the $0.47 \mathrm{~g} \mathrm{~kg}^{-1}$ of $\mathrm{P}$ in the Sabiá species (Mimosa caesalpiniifolia Benth), in a semiarid environment, applying $100 \%$ treated domestic sewage blades. R. Fia, Boas, Campos, F. Fia, and Souza (2014) verified that Tifton 85 grass presented $4.2 \mathrm{~g} \mathrm{~kg}^{-1}$ of $\mathrm{P}$ with a daily application of $0.129 \mathrm{~m}^{3} \mathrm{~d}^{-1}$ of swine wastewater. Data from Emparn (2013) shows a phosphorus content equivalent to $0.8 \mathrm{~g} \mathrm{~kg}^{-1}$. Contrasts $\mathrm{C} 1$ and $\mathrm{C} 4$ were significant at $5 \%$ and at $1 \%$ probability for phosphorus, concomitantly. There were no significant differences for potassium and magnesium among all treatments.

Vo et al. (2018), and George, Hinsinger, and Turner (2016) stated that phosphorus dynamics in soils have a direct influence on the absorption capacity of plants since this nutrient has low mobility and can be absorbed in varying concentrations throughout the life cycle of the crop. Oliveira et al. (2017), and Tocchi, Federici, Scargetta, D'annibale, and Patruccioli (2013) further point out that the availability and supply of phosphorus in fertigations with wastewater and dairy products may vary depending on the different dairy products manufactured and the reagents used in the cleanings.

The highest sodium increment in cladodes was $311.65 \mathrm{mg} \mathrm{kg}^{-1}$ after applications of $923.2 \mathrm{~m}^{3} \mathrm{ha}^{-1}$ of DWW in the treatment T5, being $89.45 \%$ higher and statistically significant in relation to the lower concentration of 164.50 $\mathrm{mg} \mathrm{kg}^{-1}$ in treatment T2. For calcium, there was a maximum increase of $139.93 \mathrm{~g} \mathrm{~kg}^{-1}$ after receiving $230.8 \mathrm{~m}^{3}$ $\mathrm{ha}^{-1}$ of DWW (T2). This result, although not significant in relation to the control, was significant in relation to the $82.33 \mathrm{~g} \mathrm{~kg}^{-1}$ obtained in the treatment T4. It was observed that, for calcium, there were significant orthogonal contrasts for $\mathrm{C} 2$ and $\mathrm{C} 4$, whereas for sodium only in $\mathrm{C} 1$.

These results were lower than those obtained by Alves et al. (2017) when evaluating the chemical and nutritional variability of cladodes of forage palm. The authors found concentrations of 2.10 and $1.40 \mathrm{~g} \mathrm{~kg}^{-1}$ of Na in secondary and tertiary branch cladodes, respectively, of forage palm after treatment with $20 \mathrm{tha}^{-1}$ of bovine manure. The same authors also observed concentrations of 3.4, 46.6, and $49.7 \mathrm{~g} \mathrm{~kg}^{-1}$ of Calcium in the second, third and fourth order cladodes, respectively. Astello-García et al. (2015) observed $2.0 \mathrm{~g} \mathrm{~kg}^{-1}$ of Na in cladodes of Opuntia spp. in studies with the domestication of cacti. Only contrasts $\mathrm{C} 1$ and $\mathrm{C} 4$ were significant (Table 3).

For Queiroz et al. (2015) the photosynthetic dynamics of the primary cladodes provides the greater vegetative performance of the cacti, providing positive effects on the absorption and distribution of nutrients and salts during the crop cycle. In this process, Taiz and Zeiger (2013), and Hernandez-Urbiola, Perez-Torrero, and Rodriguez-Garcia (2011) state that although sodium and phosphorus are essential elements in the development of cacti and have a significant role in the recomposition of phosphoenolpyruvate, transport and transduction of 
chemical energy (ATP and NADPH) during photosynthesis, when in high concentrations, the development of the culture, retaining large amounts of salts in the primary cladodes and interfering in the transport of nutrients and water to the young cladodes.

\section{Conclusion}

The dairy effluent combined with supplying water is good means of irrigation to thornless cactus, favoring the productivity and the nutritional aspect.

The dairy effluent usage in thornless cactus growth leads to a reduction of environmental damages, as by the adequate residue destination as by water saving in irrigation.

\section{References}

Agricultural Research Company of Rio Grande do Norte. (2013). Xiquexique and mandacaru in animal nutrition (p. 32). Natal: EMPARN-Agricultural Research Company of Rio Grande do Norte.

Allen, R. G., Pereira, L. S., Raes, D., \& Smith, M. (2006). Evapotranspiration of the crop: Guides for the determination of the water requirements of crops (1st ed., p. 298). Roma: FAO.

Alonso, R. A., \& Costa, L. V. C. (2017). Agronomic characters of b. brizantha cv. Xaraes (MG5), under different doses of biofertilizer of dairy cattle. Brazilian Journal of Biosystems Engineering, 11(4), 400-411. https://doi.org/10.18011/bioeng2017v11n4p400-411

Alvares, C. A., Stape, J. L., Sentelhas, P. C., Gonçalves, J. L. M., \& Sparovek, G. (2014). Köppen’s climate classification map for Brazil. Meteorologische Zeitschrift, 22(6), 711-728. https://oi.org/10.1127/ 0941-2948/2013/0507

Alves, E. M., Santos, L. J., Batista, G. S., Souza, S. R., Claudio, F. L., Júnior, G. C., \& Paim, T. P. (2017). Characteristics and productivity of experimental hybrid of Japanese pumpkin in Ipora-Brazil. Pubvet Magazine, 11(7), 662-669.

Araujo, E. F., Arauco, A. M. S., Dias, B. A. S., Silva, G. C., \& Nobrega, R. S. A. (2018). Substrates of Mauritia flexuosa and wastewater from pig farming on growth and quality in seedlings of Acacia mangium. Agronomic Science Magazine, 49(2), 298-306. https://doi.org/10.5935/1806-6690.20180034

Astello-García, M. G., Cervantes, I., Nair, V., Santos-Díaz, M. S., Reyes-Agüero, A., ... De La Rosa, A. P. B. (2015). Chemical composition and phenolic compounds profile of cladodes from Opuntia spp. cultivars with different domestication gradient. Journal of Food Composition and Analysis, 43(1), 119-130. https://doi.org/10.1016/j.jfca.2015.04.016

Barbosa, M. L., Silva, T. G. F., Zolnier, S., Silva, S. M. S., Morais, J. E. F., \& Assis, M, C. S. (2017). Association of morphological and water factors with irrigated forage cactus yield. Brazilian Journal of Agricultural and Environmental Engineering, 21(9), 600-605. https://doi.org/10.1590/1807-1929/agriambi. v21n9p600-605

Becerra-Castro, C., Lopes, A. R., Vaz-Moreira, I., Silva, E. F., Manaia, C. M., \& Nunes, O. C. (2015). Wastewater reuse in irrigation: A microbiological perspective on implications in soil fertility and human and environmental health. Journal of Environmental Management, 75(1), 117-135. https://doi.org/10.1016/ j.envint.2014.11.001

Bedbabis, S., Rouina, B. B., Boukhris, M., \& Ferrara, G. (2014). Effect of irrigation with treated wastewater on soil chemical properties and infiltration rate. Journal of Environmental Management, 133(1), 45-50. https://doi.org/10.1016/j.jenvman.2013.11.007

Bezerra, M. G. S., Silva, G. G. C., Difante, G. S., Neto, J. V. E., Oliveira, E, M. M., \& Oliveira, L. E. C. (2017). Cassava wastewater as organic fertilizer in 'Marandu' grass pasture. Brazilian Journal of Agricultural and Environmetal Engineering, 21(6), 404-409. https://doi.org/10.1590/1807-1929/agriambi.v21n6p404-409

Bjarnadóttir, M., Aðalbjörnsson, B. V., Nilsson, A., Slizyte, R., Roleda, M. Y., Hreggviðsson, G. O., ... Jónsdóttir, R. (2018). Palmaria palmata as an alternative protein source: enzymatic protein extraction, amino acid composition, and nitrogen-to-protein conversion factor. Journal of Applied Phycology, 30(3), 2061-2070. https://doi.org/10.1007/s10811-017-1351-8

Brazilian Agricultural Research Corporation. (2013). Brazilian System of Soil (3rd ed., p. 353). Brasília: Brazilian Agricultural Research Corporation-Embrapa Solos.

Caruso, C., Mauceri, C., Cavallaro, V., Borin, M., \& Barbera, A. (2018). Olive mill wastewater spreading and 
AMF inoculation effects in a low-input semi-arid Mediterranean crop succession. Journal Archives of Agronomy and Soil Science, 64(1), 2060-2074. https://doi.org/10.1080/03650340.2018.1476970

Cunha, D. de N. F. V. da, Gomes, E. dos S., Martuscello, J. A., Amorim, P. L. de, Silva, R. C., \& Ferreira, P. S. (2012). Morphometric and biomass accumulation in small forage cactus grow under nitrogen fertilization. Brazilian Journal of Animal Health and Production, 13(4), 1156-1165. https://doi.org/10.1590/ S1519-99402012000400005

Detmann, E., Souza, M. A., Valadares Filho, S. C., Queiroz, A. C., Berchielli, T. T., Saliba, E. O. S., \& Azevedo, J. A. G (2012). Methods for food analysis (1st ed., p. 214). Viçosa: National Institute of Science and Technology of Animal Science.

Donatti, R. N., Gomes, T. M., Menegassi, L. C., Tommaso, G., \& Rossi, F. (2017). Sodium phytoremediation by green manure growing in soil irrigated with wastewater of dairy industry. Agricultural Engineering Magazine, 37(4), 665-675. https://doi.org/10.1590/1809-4430-eng.agric.v37n4p665-675/2017

Doorenbos J., \& Pruitt, W. O. (1977). Guidelines for predicting crop water requirements. Rome: FAO-ONU.

Dubeux Júnior., J. C. B., Santos, M. V. F. dos, Mello, A. C. L. de, Cunha, M. V. da, Ferreira, M. A., Santos, D. C. dos, Lira, M. de A., \& Silva, M. da C. (2015). Forage potential of cacti on drylands. Acta Horticulturae, 1(1), 181-186. https://doi.org/10.17660/ActaHortic.2015.1067.24

Environmental Protection Agency. (1981). Process design manual: Land treatment of municipal wastewater (p. 625). Washington, D.C.: Environmental Protection Agency-EPA-Department of the Interior.

Ferreira, D. F. (2014). Sisvar: A Guide for its Bootstrap procedures in multiple comparisons. Science and Agrotechnology, 38(2), 109-112. https://doi.org/10.1590/S1413-70542014000200001

Fia, R., Boas, R. B. V., Campos, A. T., Fia, F. R. L., \& Souza, E. G. (2014). Removal of nitrogen, phosphorus, copper and zinc from swine breeding wastewater by bermudagrass and cattail in constructed wetland systems. Agricultural Engineering, 34(1), 112-123. https://doi.org/10.1590/S0100-69162014000100013

Formentini-Schmitt, D. M., Fagundes-Klen, M. R., Veit, M. T., Palácio, S. M., Trigueros, D. E. G., Bergamasco, R., \& Mateus, G. A. P. (2018). Potential of the Moringa oleifera saline extract for the treatment of dairy wastewater: Application of the response surface methodology. Environmental Technology, 1(1), 1-40. https://doi.org/10.1080/09593330.2018.1440012

George, T. S., Hinsinger, P., \& Turner, B. L. (2016). Phosphorus in soils and plants- facing phosphorus scarcity. Plant and Soil, 401(1), 1-6. https://doi.org/10.1007/s11104-016-2846-9

Gheri, E. O., Ferreira, M. E., \& Cruz, M. C. P. (2003). Response of Tanzânia grass to acid whey application. Brazilian Agricultural Research, 38(6), 753-760. https://doi.org/10.1590/S0100-204X2003000600012

Hernandez-Urbiola, M. I., Perez-Torrero, E., \& Rodriguez-Garcia, M. E. (2011). Chemical analysis of nutritional content of prickly pads (Opuntia ficus Indica) at varied ages in an organic harvest. International Journal Environmental research and Public Health, 8(5), 1287-1295. https://doi.org/10.3390/ijerph8051287

Kessler, N. C. H., Sampaio, S. C., Sorace, M., Lucas, S. D., \& Palma, D. (2014). Swine wastewater with mineral fertilization on corn crop (Zea mays). Agricultural Engineering Magazine, 34(3), 554-566. https://doi.org/ $10.1590 / \mathrm{S} 0100-69162014000300018$

Kihila, J., Mtei, K. M., Njau, \& K. N. (2014). Wastewater treatment for reuse in urban agriculture; the case of Moshi Municipality, Tanzania. Physics and Chemistry of the Earth, 72(1), 104-110. https://doi.org/10.1016/ j.pce.2014.10.004

Klomjek, P. (2016). Swine wastewater treatment using vertical subsurface flow constructed wetland planted with Napier grass. Sustainable Environment Research, 26(5), 217-223. https://doi.org/10.1016/j.serj.2016.03.001

Kunhikrishnan, A., Choppala, G., Seshadri, B., Wijesekara, H., Bolan, N. S., Mbene, K., \& Kim, W. (2017). Impact of wastewater derived dissolved organic carbon on reduction, mobility, and bioavailability of As (V) and $\mathrm{Cr}$ (VI) in contaminated soils. Journal of Environmental Management, 186(2), 183-191. https://doi.org/ 10.1016/j.jenvman.2016.08.020

Libutti, A., Gatta, G., Gagliardi, A., Vergine, P., Pollice, A., Beneduce, L., \& Tarantino, E. (2018). Agro-industrial wastewater reuse for irrigation of a vegetable crop succession under Mediterranean conditions. Agricultura Water Management, 196(1), 1-14. https://doi.org/10.1016/j.agwat.2017.10.015

Lima, G. F. C. da, Rego, M. M. T., Dantas, F. D. G., Lôbo, R. N. B., Sila, J. G. M., \& Aguiar, E. M. (2016). 
Morphological characteristics and forage productivity of irrigated cactus pear under different cutting intensities. Revista Caatinga, 29(2), 481-488. https://doi.org/10.1590/1983-21252016v29n226rc

Mantovani, E. C., \& Costa, L.C. (1998). Integrated management of crops and water resources (p. 154). Brasília: SRH/MMA-DEA-UFV.

Marques, B. C. D., Cunha, V. T., Cunha, V. T., Silva, K. B., \& Batista, R. O. (2016). Performace of drippers operating with dairy wastewater at laboratory scale. Irriga, 21(1), 140-155. https://doi.org/10.15809/ irriga.2016v21n $1 \mathrm{p} 140-155$

Mathiyarasu, R., Seshadri, B., Kumar, P., Shilpi, S., Bolon, N., \& Naidu, R. (2017). The Effect of Wastewater Irrigation Rate on Dry Matter Yield of Selected Field Crops. Internatinal Journal of Water and Wastewater Treatment, 3(1), 1-9. https://dx.doi.org/10.16966/2381-5299.142

Mesquita, F. O. (2016). Performance of drippers and elephant grass production (Pennisetum purpureum Schum.) with semi-arid landfill percolation (Doctoral Thesis, Federal Rural University of the Semi-Arid, Mossoró, RN). Retrieved from http://bdtd.ufersa.edu.br/handle/tede/693

Moraes, S. A., Costa, S. A. P., \& Araújo, G. G. L. (2011). Nutrição e Exigências Nutricionais. In T. V. Voltolini (Ed.), Produção de caprinos e ovinos no Semiárido (pp. 165-200). Petrolina: Embrapa Semi-árido.

Moreira, G. L. P., Prates, C. J. N., Oliveira, L. M., Viana, A. E. S., Cardoso Júnior, N. S., \& Figueiredo, M. P. (2017). Bacteriological composition of manioc (Manihot esculenta) as of the interval between pruning. Journal of Agricultural Sciences, 40(1), 144-153. https://dx.doi.org/10.19084/RCA16022

Morrill, W. B. B., Rolim, M. M., Bezerra Neto, E., Pedrosa, E. M. R., Oliveira, V. S., \& Almeida, G. L. P. (2012). Productivity and mineral nutrients em millet and Sudan grass fertilized with whey. Brazilian Journal of Agricultural and Environmental Engineering, 16(2), 182-188. https://doi.org/10.1590/ S1415-43662012000200008

Oliveira, J. F., Rodrigues, F. N., Fia, R., Vilela, H. S., \& Mafra, D. C. B. (2017). Performance of tifton 85 grass under fertirrigation with slaughterhouse wastewater. Agricultural Engineering, 37(4), 790-800. https://doi.org/10.1590/1809-4430-eng.agric.v37n4p790-800/2017

Pereira, P. C., Silva, T. G. F., Zolnier, S., Morais, J. E. F., \& Santos, D. C. (2015). Growth evolution of cactus forage drip irrigated. Caatinga Magazine, 28(3), 184-195. https://doi.org/10.1590/1983-21252015v28 $\mathrm{n} 321 \mathrm{rc}$

Queiroz, M. G., Silva, T. G. F., Zolnier, S., Silva, S. M., Lima, L. R., \& Alves, J. O. (2015). Morphophysiological characteristic and yield of forage cactus under diferent irrigation depths. Brazilian Journal of Agricultural and Environmental Engineering, 19(10), 931-938. https://doi.org/10.1590/ 1807-1929/agriambi.v19n10p931-938

Rodríguez-Liébana, J. A., Elgouzia, S., Mingorancea, M. D., Castilloa, A., \& Peña, A. (2014). Irrigation of a Mediterranean soil under field conditions with urban wastewater: effect on pesticide behaviour. Agriculture, Ecosystems \& Environment, 185(1), 176-185. https://doi.org/10.1016/j.agee.2013.12.026

Santos, G. O., Faria, R. T., Rodriguês, G. A., Dantas, G. F., Dalri, A. B., \& Palaretti, L. F. (2017). Forage yield and quality of marandugrass fertigated with treated sewage wastewater and mineral fertilizer. Acta Scientiarum, 39(4), 515-523. https://doi.org/10.4025/actasciagron.v39i4.32828

Saraiva, C. B., Matos, A. T., Matos, M. P., \& Miranda, S. T. (2018). Influence of substrate and species arrangement of cultivated grasses on the efficiency of horizontal subsurface flow constructed wetlands. Agricultural Engineering, 38(3), 417-425. https://doi.org/10.1590/1809-4430-eng.agric.v38n3p417-425/2018

Silva, F. C. (2009). Manual of chemical analysis of soils, plants and fertilizers (2nd ed., p. 627). Brasília: Embrapa Information Technology.

Silva, J. A., Donato, S. L. R., Donato, P. E. R., Souza, E. S. S., Padilha Júnior, M. C., \& Silva Júnior, A. A. (2016). Yield and vegetative growth of cactus pear at different spacings and under chemical fertilizations. Brazilian Journal of Agricultural and Environmental Engineering, 20(6), 564-569. https://doi.org/10.1590/ 1807-1929/agriambi.v20n6p564-569

Solati, Z., Jorgensen, U., Eriksen, J., \& Soegaard, K. (2017). Dry matter yield, chemical composition and estimated extractable protein of legume and grass species during the spring growth. Journal of the Food and Agriculture, 97(12), 3958-3966. https://doi.org/10.1002/jsfa.8258

Souza, T. C., Santos, M. V. F., Dubeux Júnior, J. C. B., Lira, M. A., Santos, D. C., Cunha, M. V., \& Silva, R. R. 
(2017). Productivity and nutrient concentration in spineless cactos under different fertilizations and plant densities. Brazilian Journal of Agricultural Sciences, 12(4), 555-560. https://doi.org/10.5039/agraria. v12i4a5473

Taiz, L., \& Zeiger, E. (2013). Plant Physiology (5th ed., p. 918p). Brazil, Porto Alegre: Artemed.

Tocchi, C., Federici, E., Scargetta, S., D’annibale, A., \& Patruccioli, M. (2013). Dairy wastewater polluting load and treatment performances of an industrial three-cascade-reactor plant. Process Biochemistry, 48(5-6), 941-944. https://doi.org/10.1016/j.procbio.2013.04.009

Van Soest, P. J. (1965). Symposium on factors influencing the voluntary intake of herbage by ruminants: Voluntary intake relation to chemical composition and digestibility. Journal of Animal Science, 24(3), 834-844. https://doi.org/10.2527/jas1965.243834x

Vo, T. D. H., Bui, X. T., Nguyen, D. D., Nguyen, V. T., Ngo, H. H., Guo, W., ... Lin, C. (2018). Wastewater treatment and biomass growth of eight plants for shallow bed wetland roofs. Bioresource Technology, 247(1), 992-998. https://doi.org/10.1016/j.biortech.2017.09.194

\section{Copyrights}

Copyright for this article is retained by the author(s), with first publication rights granted to the journal.

This is an open-access article distributed under the terms and conditions of the Creative Commons Attribution license (http://creativecommons.org/licenses/by/4.0/). 